\title{
Transformations of Reproductive Behavior During the Fertility Transition: a Family Reconstitution Study of a Finnish Parish
}

\section{IRMA-LEENA NOTKOLA}

Assistant

Department of Community Health

and General Practice

University of Kuopio

\section{Introduction}

In the first half of the 19th century, both birth rates and death rates were high in Europe; birth rates were about 40 per 1,000 persons and death rates $20-30$ per 1,000 persons. These rates have drastically declined since the beginning of the 19 th century. Now, most birth rates are under 15 per 1,000 persons and death rates are at a level of about 10 per 1,000 persons. These changes in fertility and mortality are together called the »demographic transition of Europe» according to a general »theory of demographic transition", which is based on the experience of Western Europe. Consequently the historical fertility decline may be called fertility transition.

There is no disagreement about the behavioral background of the historical fertility decline: it was caused by the diffusion of deliberate birth control. There has been more debate about the nature of reproductive behavior in the pretransitional period, the main question being whether deliberate birth control was practiced before the transition. The results of the first studies based on family reconstitution data in the 1960's and 1970's were commonly interpreted as showing deliberate family limitation in the pretransitional population examined (see e.g. Wrigley 1966, 91-105; Gaunt 1973, 40-50; Winberg 1975, 231-245). Wilson (1984, 240) has, however, challenged the statistical as well as substantial significance of these studies because their results are based on small populations over short periods. The results of the later studies based on family reconstitution data from several English parishes as well as German villages, have led to the conclusion that there is no convincing evidence for family limitation in these pretransitional populations (Knodel 1978b, Wilson 1984). In any case, the pretransitional level of marital fertility was rather low. The reasons for this low level are not wholly understood, but there is convincing evidence of an adverse effect from long-lasting intensive breast-feeding on fertility in historical populations (e.g. Lithell 1981). As regards the fertility transition, knowledge about behavioral changes other than the diffusion of family limitation is largely lacking.

The purpose of this paper is to describe the transformations of reproductive behavior during fertility transition in a Finnish parish using family reconstitution data. The interest is not restricted to the emergence of concise birth control, but the be- 
havioral side of natural fertility ${ }^{1}$ is also intensively examined. Knowledge about typical reproductive behavior before and during the transition is necessary for understanding and explaining the transition. ${ }^{2}$

\section{Conceptual background}

The following analyses are based on the conceptual separation of $»$ natural fertility» and "family limitation». Henry $(1961,81)$ has defined natural fertility as marital fertility in the absence of deliberate birth control. By birth control he means behavior which is bound to the number of children already born and is modified when the desired family size or parity is reached. However, since it is possible to control fertility deliberately also by spacing births, it has become established to use the term »birth control» as a general concept to refer to any kind of deliberate action to space or prevent births. On the other hand, the term »family limitation» has been introduced to refer to parity-dependent birth control, i.e. birth control in Henry's sense (e.g. Knodel 1978b, 482; Wilson 1984, 229). In these terms, which are used in the present paper, natural fertility can be defined as marital fertility in the absence of family limitation (cf. Knodel 1978b, 482).

Fertility variations can always be traced to variations in one or more intermediate variables. The intermediate fertility variables were first introduced in the mid-1950s by Davis and Blake (1956), who defined them as the factors through which, and only through which, social economic and cultural factors can affect fertility. In place of Davis \& Blake's original set of 11 intermediate variables, Bongaarts (1982) has devised a new set of 7 intermediate variables. This new set is as comprehensive as the original set but it is simpler and more usable in quantitative reproductive models. Bongaarts has named the intermediate variables as the following:

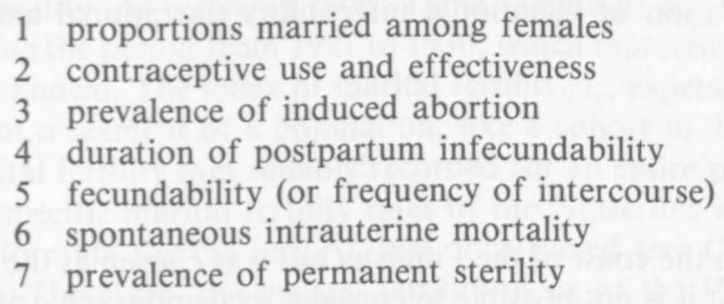

From the analytical point of view of this study, the most important are the last four variables, which are the factors determining the level of natural fertility. Bongaarts (loc. cit.) has shown that variation in the duration of postpartum infecundity explains almost wholly the variation of natural fertility between populations; the other three determinants of natural fertility have only minor effects. There is, further, strong evidence that the variation in the duration of postpartum infecundity depends mostly on the duration and intensity of breast-feeding (e.g. Billewicz 1979). Intensive breastfeeding inhibits ovulation and causes temporal infecundity (see McCann et al. 1984,

' By wnatural fertility" we refer to marital fertility in the absence of family limitation, see Ch. 2.

2 This article is based on the author's doctoral thesis »Luonnollisesta hedelmällisyydestä lapsirajoitukseen: mikrodemografinen tutkimus hedelmällisyyden transitiosta» (From natural fertility to family limitation: A family reconstitution study of fertility transition in Finland.) Publications of the Finnish Demographic Society, No. 12, Kuopio 1989. (Diss.) 
Figure 1. Location of Virolahti.

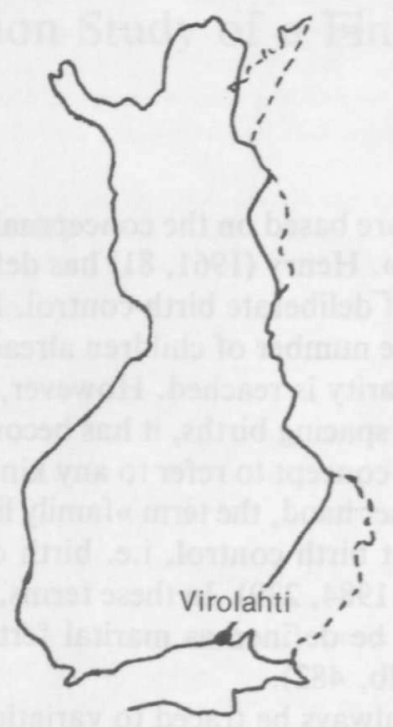

539-544), which may last over 2 years (Konner \& Worthman 1980). In conclusion, the most important behavioral factor behind natural fertility which should be detected by analysis is the duration of lactational infecundity (lactational amenorrhoea). ${ }^{3}$

\section{Data}

The parish of Virolahti on the coast of the Finnish Gulf was chosen as the study area (Figure 1). In this context it is not possible to consider its demographic and socioeconomic characteristics and development in the 19th and in the 20th very thoroughly. Only some main points are presented. Virolahti belonged to the province of Viipuri (since the 1940s to the province of Kymi). It had a population of $7,000-8,000$ in the years 1850 - 1950 (the population of Miehikkälä which was separated from Virolahti as an independent municipality in the $1880 \mathrm{~s}$ is not included in these figures). Population statistics show that the secular decline of marital fertility started at the very beginning of this century, which is some 10 years earlier than in the whole province of Viipuri and in the whole of Finland. Most people were working in agriculture as farmers or as workers; the proportion of workers increased from the 19 th $(20-25 \%)$ to the first half of the 20 th century $(40 \%)$. Most of the farms were quite small. Through subsidiary industries, viz. the stone industry, shipping, and fishing, people had contacts especially is St. Petersburg, Viipuri and Estonia.

${ }^{3}$ For a fuller discussion of the conceptual background, see Notkola 1989. 
The data used in the following analyses consist of 1,594 reconstituted family histories of women who were born between the years 1830 and 1909 and lived in Virolahti for their entire reproductive marital span. The demographic events for the family histories were collected from the parish records of Virolahti. For the analyses the women were divided into 10 -year or 20 -year cohorts according to their year of birth.

\section{Results}

Family reconstitution data make it possible to calculate macro-level as well as micro-level measures of fertility and child mortality. We begin with common aggregate measures to get to know the level, fluctuations and secular changes in marital fertility and infant and child mortality. We continue with more specific measures to study, firstly, the presence or absence of family limitation and, secondly, the duration of lactational infecundity.

\section{Total marital fertility}

Table 1 presents the total marital fertility rates (TMFR) and Coale's indices of marital fertility $\left(I_{g}\right)$ for the different cohorts. These measures are based on the agespecific marital fertility rates of the cohorts. (The formulas are given in Table 1.) The TMFR and $\mathrm{I}_{\mathrm{g}}$ are both useful measures for comparing the overall level of marital fertility of two or more populations or groups. This is, however, strictly true only for populations with natural fertility. If parity-specific birth control is practiced, both measures depend on the age structure of married women, i.e. on the average age at marriage. Because the differences in the mean age at the first marriage between the study cohorts were fairly small, at the most about two years, the use of these measures is appropriate in this study for purposes of describing the level of fertility. As reference rates, Table 1 contains the TMFR's for married Hutterites during the period from 1921 to 1930 , which represent the maximum marital fertility ever known. The index of marital fertility, $I_{g}$, expresses the fertility of a population (or of a segment of a population, like a cohort in this case) relative to the highest marital fertility ever reliably recorded for an entire population. In other words, the age-specific marital fertility rates of the Hutterites were chosen as standards when the formula for the index $\mathrm{I}_{\mathrm{g}}$ was constructed (see Coale \& Treadway 1986, 153 162). Therefore, the marital fertility index of the Hutterites has the value of 1.

Table 1. Total marital fertility rates (TMFR) and indices of marital fertility $\left(\mathrm{I}_{\mathrm{g}}\right)$ for different cohorts and Hutterites (reference group).

$\begin{array}{lccccccccr}\text { Cohort } & 1830 & 1840 & 1850 & 1860 & 1870 & 1880 & 1890 & 1900 & \text { Hutte- } \\ & -39 & -49 & -59 & -69 & -79 & -89 & -99 & -09 & \text { rites } \\ \text { TMFR } & 7.7 & 6.9 & 7.6 & 8.2 & 7.0 & 5.7 & 5.3 & 4.6 & 10.9 \\ \mathrm{I}_{8} & .70 & .63 & .68 & .76 & .63 & .50 & .44 & .37 & 1.0\end{array}$

TMFR $=5 \Sigma f_{j}$ summed over all the five-year age groups from $20-24$ to $45-49 ; f_{j}$ refers to the marital fertility rate of the age group $j$.

$I_{g}=\frac{\Sigma M_{j} f_{j}}{\Sigma M_{j} F_{j}}$ summed over all the five-year age groups from $20-24$ to $45-49 ; M_{j}$ refers to the marital women-years lives in the age group $\mathrm{j} ; \mathrm{F}_{\mathrm{j}}$ refers to Hutterites' fertility rate of the age group $\mathbf{j}$. 
The starting point of the secular fertility decline may be put at the cohort where the $\mathrm{I}_{\mathrm{g}}$ index had fallen 10 percent below its peak recorded level, never to return again (cf. van de Walle and Knodel 1980, 30). In the study area the 90 percent level was reached at the cohort of $1870-79$. The pretransitional values of $I_{g}$ fluctuated between .63 and .76 . These values, although they are some 30 percent lower than the value of the Hutterites, do not differ from the typical values in Europe in the pretransitional period. The pre-decline level varied from country to country, but was usually between .60 and .80 (van de Walle \& Knodel 1980, 17, 32). For the whole of Finland the value was about .70 (Lindgren 1980, 89; van de Walle \& Knodel 1980, 32; Coale \& Treadway 1986,93$)$.

\section{Infant and child mortality rates}

The life table measure of child mortality $\left({ }_{15} \mathrm{q}_{0}\right)$ used in Table 2 indicates the overall level of child mortality in different cohorts. It expresses the proportion of children dying between birth and age 15 . The cohorts for which these rates are calculated are formed in the same way as in the tables concerning fertility, i.e. by the year of birth of the mothers. For example, the ${ }_{15} \mathrm{q}_{0}$ for the cohort $1830-39$ expresses the mortality of the children whose mothers belong to the birth cohort $1830-39$. In the oldest three cohorts, almost one-third of the children died before age 15 . The secular decline of child mortality began at the cohort $1860-69$, and in the youngest cohort over $90 \%$ of the children survived to age 15 .

In Figure 2 infant mortality and older child mortality are separated, and the trends of two measures of child mortality, $\mathrm{q}_{0}$ and ${ }_{14} \mathrm{q}_{1}$, are presented. The first expresses the probability of not surviving from birth to age 1 , and the second the probability of not surviving from age 1 to age 14 .

The decline of infant mortality started, little by little, at the cohort $1850-59$ and got stronger from the cohort $1870-79$. The mortality of children aged between 1 and 14 began at the cohort $1860-69$. As it was the cohort $1870-79$ which started the fertility transition, it seems that the decline of child mortality began somewhat earlier than the decline of marital fertility in this area.

\section{Measures of family limitation based on age-specific fertility rates}

The TMFR and $I_{g}$ reveal the levels and changes in marital fertility, but they give no information about the reasons for the relatively low pre-decline level of fertility or for the secular changes in fertility. The age-specific marital fertility rates contain more information in this respect, since they make it possible to separate populations (or cohorts) with natural fertility from populations (or cohorts) with family limitation. In natural fertility situations the couples continue to have children as long as the spouses are fecund, but where family limitation is common, the couples tend to terminate childbearing at an earlier age. The age pattern of marital fertility reflects these behavioral differences as follows: if fertility is natural, the age-specific marital fertility rates stay at quite a high level until age $35-39$, after which they fall off drasti-

Table 2. Proportions of live-born children dying before age $15\left({ }_{15} \mathrm{q}_{0}\right)$ in different cohorts.

$\begin{array}{lllllllll}\text { Cohort } & 1830 & 1840 & 1850 & 1860 & 1870 & 1880 & 1890 & 1900 \\ & -39 & -49 & -59 & -69 & -79 & -89 & -99 & -09 \\ { }_{15} \mathrm{q}_{0} & 0.31 & 0.29 & 0.29 & 0.26 & 0.19 & 0.17 & 0.12 & 0.06\end{array}$


Figure 2. Infant mortality rates $\left(\mathrm{q}_{0}\right)$, child mortality rates $\left({ }_{14} \mathrm{q}_{1}\right)$ and indices of marital fertility $\left(\mathrm{I}_{\mathrm{g}}\right)$ by mother's cohort.

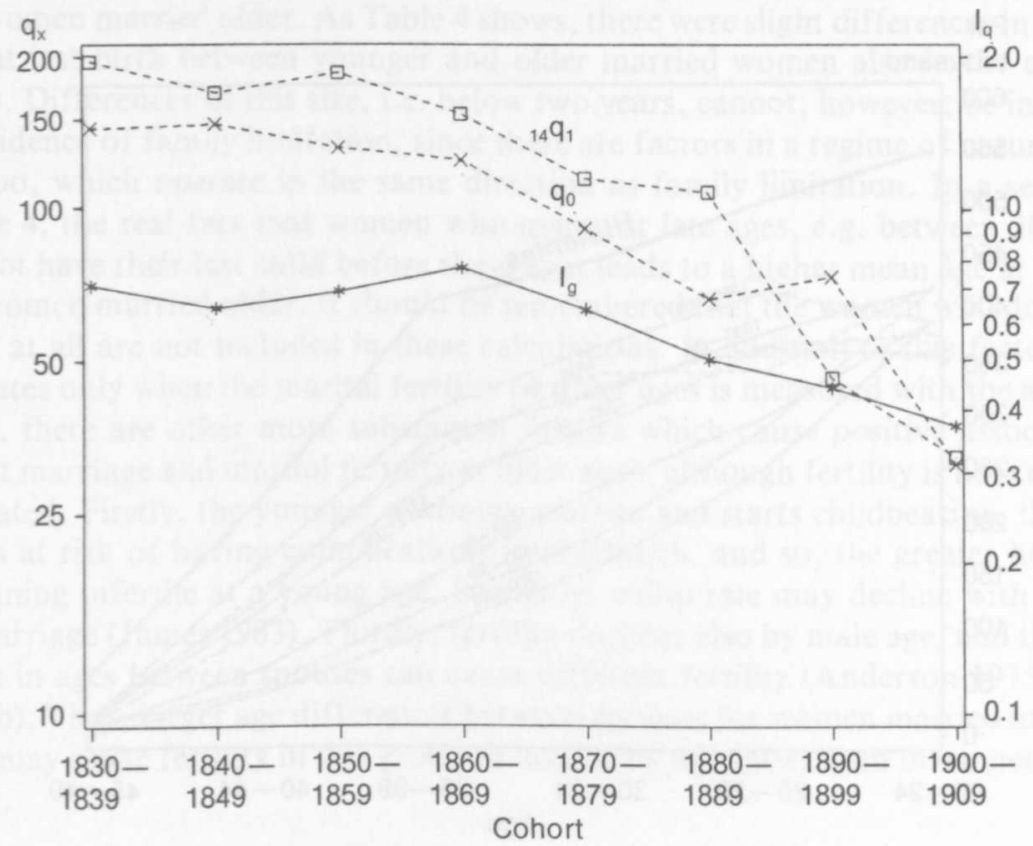

cally; if fertility is parity-specifically controlled, age-specific marital fertility rates start to decline in younger age groups - the younger this happens, the more effective family limitation is. The age-specific marital fertility rates of the study cohorts are presented in Figure 3. The curves of the pretransitional cohorts (from cohort $1830-39$ to cohort $1860-69$ ) are clearly concave, suggesting that fertility was natural. The curves of cohorts $1880-89$ to $1900-09$ are, on the contrary, clearly convex, suggesting that family limitation was practiced. Cohort $1870-79$, which we above inferred to have started the fertility transition, has a curve not differing very much from the curves of the older cohorts, but the lower rates at ages 35-39 and older refer to a change toward family limitation.

Coale and Trussel (1978) have developed an index of family limitation called m, which contains the same information as age-specific fertility rates but in the form of one figure. The index measures the speed of marital fertility decline by age in a given population compared to a "standard» natural fertility pattern. The value of the index m depends only on the shape of the age-specific marital fertility curve, not on the level of marital fertility. It gets the value of zero if the shape of the fertility schedule in question does not differ from the natural fertility schedule. It will get a higher value the faster marital fertility falls with age. Coale and Trussel emphasize that small deviations from zero do not necessarily indicate the practice of family limitation. They suggest that populations with values under 0.2 should be interpreted as having natural fertility (Coale and Trussel 1978, 205).

The values of the $\mathrm{m}$ index for the different cohorts (Table 3) conform to the inference based on the respective age-specific fertility rates, i.e. that the practice of family limitation was started by the cohort $1870-79$. Until the cohort $1870-79$ the index fluctuated under the level of 0.2 . It rose over the value of 0.2 at the cohort $1870-79$ and from this cohort onward the value of $\mathrm{m}$ steadily increased. 
Figure 3. Age-specific fertility rates for the cohorts and Hutterites.

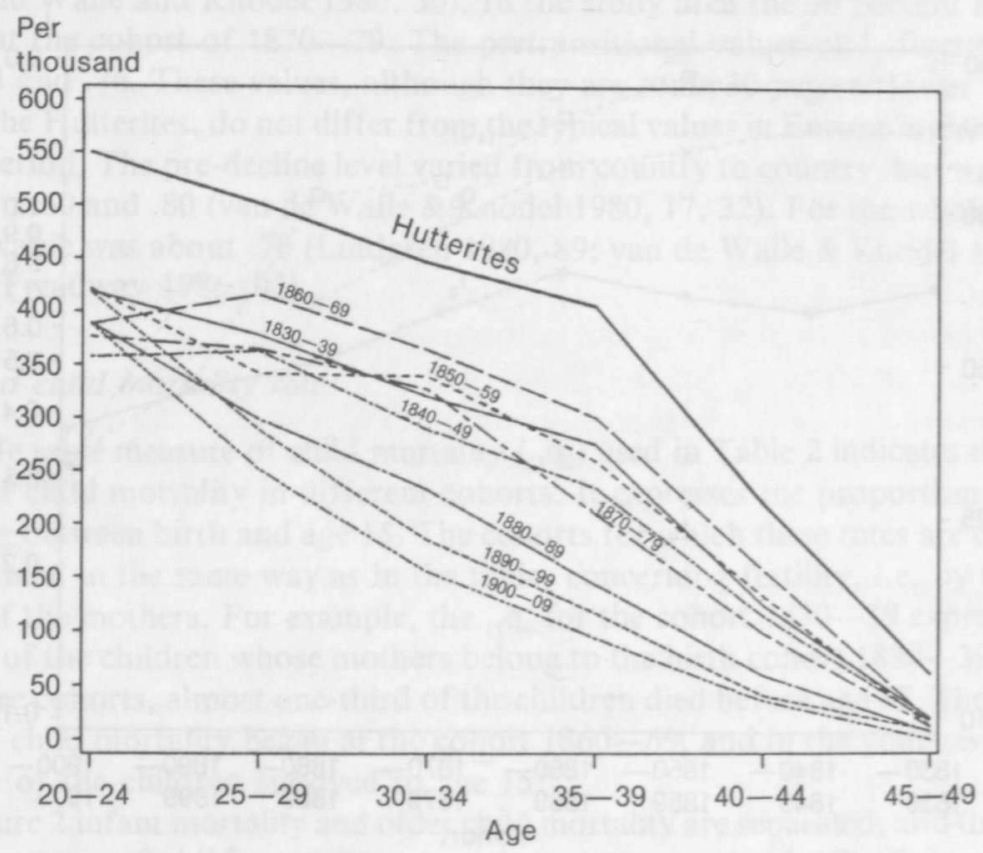

Table 3. Index of family limitation by cohort.

$\begin{array}{lllllllll}\text { Cohort } & 1830 & 1840 & 1850 & 1860 & 1870 & 1880 & 1890 & 1900 \\ & -39 & -49 & -59 & -69 & -79 & -89 & -99 & -09 \\ \mathrm{~m} & 0.10 & 0.12 & 0.05 & -0.04 & 0.27 & 0.60 & 0.88 & 0.95\end{array}$

\section{Age at last birth}

One further measure of family limitation, which has been widely used in family reconstitution studies, is the age of the mother at last birth. Analysis of the mean age at which women cease childbearing is based on a hypothesis that in a natural fertility setting the age at marriage does not have any effect on the ceasing of childbearing, whereas in a controlled fertility setting, the earlier a woman is married the younger she, on average, stops childbearing.

The mean ages at last birth for different cohorts were calculated separately for two marital age groups, using as the dividing point the marital age of 25 years (Table 4). In the oldest cohorts the age of the mother at her last birth was near the age of 40 regardless of her age at marriage. In the later cohorts women were, on average, younger when they ceased childbearing. In all of the cohorts, the age at last birth for women married older was higher, but this difference got larger in the youngest cohorts. These results provide additional evidence for the argument that the fertility transition was caused by wider and wider use of birth control. 
Under a regime of controlled fertility, marital fertility of older ages will be positively associated with age at marriage and so the mean age at last birth will be higher for women married older. As Table 4 shows, there were slight differences in the mean age at last birth between younger and older married women also in the oldest cohorts. Differences of this size, i.e. below two years, cannot, however, be interpreted as evidence of family limitation, since there are factors in a regime of natural fertility, too, which operate in the same direction as family limitation. In a setting like Table 4, the real fact that women who marry at late ages, e.g. between 30 and 35 , cannot have their last child before these ages leads to a higher mean age at last birth for women married older. It should be remembered that the women who do not give birth at all are not included in these calculations. In addition to this factor, which operates only when the marital fertility of older ages is measured with the age at last birth, there are other more substantial factors which cause positive association of age at marriage and marital fertility at older ages, although fertility is not conciously limitated. Firstly, the younger a woman marries and starts childbearing, the longer she is at risk of having complications in childbirth, and so, the greater her risk of becoming infertile at a young age. Secondly, coital rate may decline with duration of marriage (James 1983). Thirdly, fertility declines also by male age, and the differences in ages between spouses can cause different fertility (Anderson 1975; Knodel 1978b). Thus, larger age differences between spouses for women married at younger ages may cause fertility in this group to decline by age faster than in women married older.

\section{Child mortality, family limitation and birth intervals}

It is possible to study further the behavioral background of fertility in the course of the transition by analyzing the relationship between child mortality and fertility at the family level. The two ways that child mortality may affect fertility at the individual couple level are commonly called the "physiological» and the »replacement» effect (Knodel 1978a and 1979). The physiological effect refers to an involuntary mechanism operating through lactational amenorrhoea: intensive breast-feeding inhibits ovulation and menstruation and, thus, also inhibits a new pregnancy; but if the child dies, the inhibitory effect of breast-feeding ceases and a new pregnancy is possible. The replacement effect refers to volitional behavior and is present when parents continue bearing children, compensating for those who die young, until they reach the number of surviving children they consider sufficient. The replacement effect operates only in contexts where couples limit their fertility after they reach some number

Table 4. Mean age at last birth by age at marriage for different cohorts, completed unions only.

$\begin{array}{lllllllll}\begin{array}{l}\text { Age at } \\ \text { marriage }\end{array} & 1830 & 1840 & 1850 & 1860 & 1870 & 1880 & 1890 & 1900 \\ \begin{array}{l}\text { Under } 25 \\ \quad-39\end{array} & -49 & -59 & -69 & -79 & -89 & -99 & -09 \\ \quad \begin{array}{l}\text { Mean } \\ \text { (n) }\end{array} & 38.8 & 38.4 & 39.3 & 39.4 & 38.0 & 34.2 & 33.9 & 31.3 \\ \begin{array}{l}\text { 25 orer } \\ \text { or ove }\end{array} & (72) & (75) & (81) & (88) & (80) & (68) & (56) & (64) \\ \quad \begin{array}{l}\text { Mean } \\ \text { (n) }\end{array} & 40.2 & 39.7 & 39.2 & 40.5 & 38.9 & 37.3 & 36.3 & 36.4 \\ & (40) & (45) & (59) & (63) & (43) & (42) & (53) & (48)\end{array}$

Notes: wcompleted unions" refers to marriages in which the wife reached at least age 45 by the time the marriage ended; $\mathrm{n}=$ number of cases. 
of children they do not wish to exceed, i.e. where fertility is parity-specifically controlled. Where natural fertility prevails, childbearing continues among all couples until one of the spouses becomes permanently sterile or dies and is independent of the number of children that have survived or died. Thus, if the results of analysis of empirical data show no replacement effect, common practicing of parity-specific birth control is not likely. On the other hand, no physiological effect is necessary in a setting of natural fertility, but its presence implies that breast-feeding is common and affects fertility.

One way to study the replacement effect at the family level is to find out whether progression ratios at a given parity differ according to the previous experience of child deaths. Table 5 presents parity progression ratios by cohort according to whether or not couples have experienced child deaths. It is expected that, if fertility is parityspecifically controlled, at a given parity those parents who have had child deaths are more willing to have more children than those whose children are all living. There seems not to have been any replacement effect in the oldest cohorts, 1830-1849 and $1850-69$, but it emerged in the 20 -year cohort $1860-79$, in which parents with experiences of previous child deaths progressed to the following parity more often than parents without previous child deaths in every parity from three onward. In the last 20-year cohort the replacement effect can be seen only in the parity three. These results confirm the inference made in the previous analyses that there was no family limitation in the cohorts $1830-39$ to $1860-69$ and that family limitation emerged in the first transitional cohort, that is $1870-79$. A reason for indifferent progression ratios in the last 20 -year cohort from the replacement point of view may be the inability of this method to take parents' different family size goals into account.

A clear physiological effect is seen in Table 6 , which presents mean intervals between births according to the survival of the child born at the beginning of the interval. If women breast-feed with frequent nursing bouts, postpartum ovulation will be suppressed and a new pregnancy postponed. Breast-feeding women are protected against a new pregnancy as long as intensive breast-feeding lasts (e.g. Howie and

Table 5. Percentage of women in completed families who progress to next parity by parity and the number of child deaths experienced before the latest birth.

\begin{tabular}{lcccccccc}
\multicolumn{1}{c}{} & \multicolumn{2}{c}{ 2nd to 3rd } & \multicolumn{3}{c}{ 3rd to 4th } & \multicolumn{3}{c}{ 4th to 5th } \\
Cohort & $\begin{array}{c}\text { None } \\
\text { died }\end{array}$ & $\begin{array}{c}\text { One } \\
\text { died }\end{array}$ & $\begin{array}{c}\text { None } \\
\text { died }\end{array}$ & $\begin{array}{c}\text { One } \\
\text { died }\end{array}$ & $\begin{array}{l}\text { Two } \\
\text { died }\end{array}$ & $\begin{array}{c}\text { None } \\
\text { diéd }\end{array}$ & $\begin{array}{c}\text { One } \\
\text { died }\end{array}$ & $\begin{array}{l}\text { Two } \\
\text { died }\end{array}$ \\
$1830-49$ & 94 & 96 & 93 & 88 & $(82)$ & 94 & 91 & 100 \\
$1850-69$ & 94 & 89 & 94 & 94 & $\ldots$ & 95 & 84 & 100 \\
$1870-79$ & 86 & 86 & 86 & 91 & $\ldots$ & 78 & 95 & $\ldots$ \\
$1890-1909$ & 78 & $(75)$ & 67 & 81 & $\ldots$ & 71 & 52 & $\ldots$
\end{tabular}

5th to 6 th

$\begin{array}{lcc}\begin{array}{l}\text { None } \\ \text { died }\end{array} & \begin{array}{c}\text { One } \\ \text { died }\end{array} & \begin{array}{l}\text { Two } \\ \text { died }\end{array} \\ 78 & 87 & 91 \\ 91 & 89 & 91 \\ 80 & 87 & (93) \\ 65 & (70) & .\end{array}$

Note: ... indicates a result not shown because of fewer than 10 cases;

0 indicates a result based on $10-19$ cases. 
Table 6. Mean intervals in months between births according to the survival time of the previously born child, by cohort.

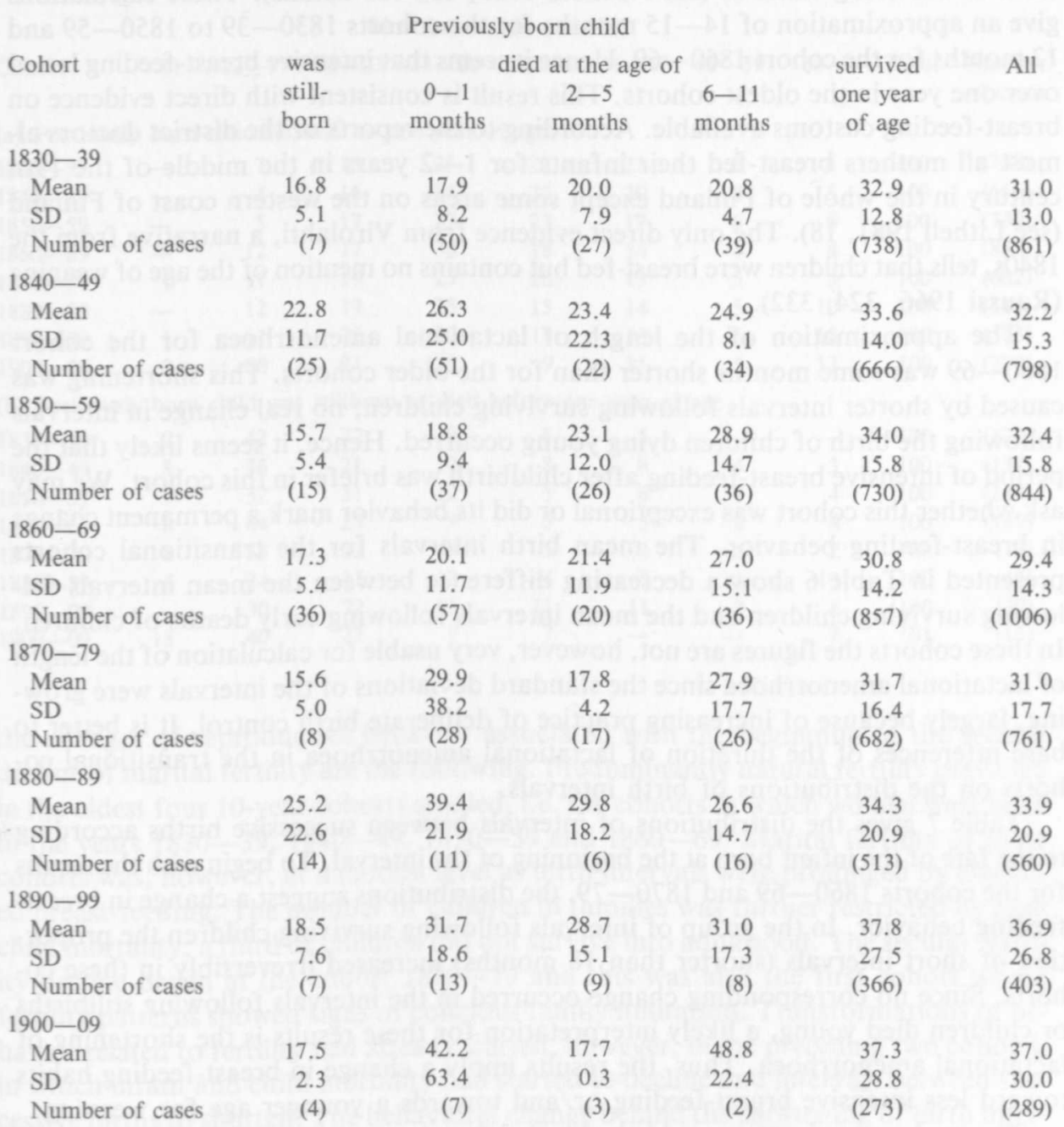

McNeilly 1982). The death of the child who is breast-fed cuts the lactation and the contraceptive effect disappears. So, in populations with long-lasting intensive breastfeeding, shorter birth intervals are expected for those women whose preceding child has died very young than for those whose preceding child survives at least its first year. On the other hand, if women do not breast-feed or breast-feed only briefly, potential fertility will return shortly after the birth of a child and, if no concious birth control is practiced, the birth intervals after each child will be short whether or not the preceding child survives.

In the study area in the pretransitional cohorts, the birth intervals following infant deaths were, on average, considerably shorter than the birth intervals where the first-born child survived its first year. Moreover, the birth intervals following infant deaths were the longer the longer the preceding child survived. These features are typical for a population in which breast-feeding is common. Since these cohorts had - according to the previous analyses - natural fertility, it is possible to infer an approximate duration of lactational infecundity from the figures in Table 6 . This 
can be calculated by subtracting the mean intervals following the birth of children who died before they were two months old from the mean intervals following the birth of surviving children (see Notkola 1989, 130 for details). These calculations give an approximation of $14-15$ months for the cohorts $1830-39$ to $1850-59$ and 12 months for the cohort $1860-69$. Hence it seems that intensive breast-feeding lasted over one year in the oldest cohorts. This result is consistent with direct evidence on breast-feeding customs available. According to the reports of the district doctors almost all mothers breast-fed their infants for $1-2$ years in the middle of the 19th century in the whole of Finland except some areas on the western coast of Finland (see Lithell 1981, 18). The only direct evidence from Virolahti, a narrative from the 1840 s, tells that children were breast-fed but contains no mention of the age of weaning (Raussi 1966, 324, 332).

The approximation of the length of lactational amenorrhoea for the cohort 1860-69 was some months shorter than for the older cohorts. This shortening was caused by shorter intervals following surviving children; no real change in intervals following the birth of children dying young occurred. Hence, it seems likely that the period of intensive breast-feeding after childbirth was briefer in this cohort. We may ask whether this cohort was exceptional or did its behavior mark a permanent change in breast-feeding behavior. The mean birth intervals for the transitional cohorts presented in Table 6 show a decreasing difference between the mean intervals following surviving children and the mean intervals following early deaths of children. In these cohorts the figures are not, however, very usable for calculation of the length of lactational amenorrhoea since the standard deviations of the intervals were growing, largely because of increasing practice of deliberate birth control. It is better to base inferences of the duration of lactational amenorrhoea in the transitional cohorts on the distributions of birth intervals.

Table 7 gives the distributions of intervals between successive births according to the fate of the infant born at the beginning of the interval. To begin with the results for the cohorts $1860-69$ and $1870-79$, the distributions suggest a change in breastfeeding behavior. In the group of intervals following surviving children the proportion of short intervals (shorter than 18 months) increased irreversibly in these cohorts. Since no corresponding change occurred in the intervals following stillbirths or children died young, a likely interpretation for these results is the shortening of lactational amenorrhoea. Thus, the results imply a change in breast-feeding habits toward less intensive breast-feeding or/and towards a younger age for weaning.

The tendency to have a new birth shortly after the preceding surviving infant got stronger in the youngest cohorts. There is, however, another striking change in the distributions of the three youngest 10 -year cohorts. The proportion of very long, longer than 60 months, intervals increased systematically in sequential cohorts. This change is more steady in intervals following surviving children, but it can be seen also in intervals following children who were stillborn or who died before one year of age. The increase of long intervals probably reflects failures in contraception and changes in decisions concerning the final family size.

\section{Discussion}

In this article the behavioral changes underlying the European fertility transition have been approached by investigating the reconstituted family histories of couples from a Finnish parish. The main conclusions about the timing of the transition and 
Table 7. Frequency distribution of intervals between births according to the survival of the previously born child, by cohort.

Birth interval in months

$\begin{array}{llllllllll}\text { Cohort } & -11 & 12-17 & 18-23 & 24-29 & 30-35 & 36-47 & 48-59 & 60- & \text { Total } \begin{array}{l}\text { Number } \\ \text { of cases }\end{array}\end{array}$

(a) Previously born child survived to one year of age

$\begin{array}{rrrlllllll}1830-39 & - & 7 & 15 & 25 & 23 & 21 & 6 & 4 & 100 \\ 1840-49 & - & 4 & 16 & 24 & 25 & 20 & 6 & 5 & 100 \\ 1850-59 & - & 5 & 17 & 27 & 22 & 17 & 6 & 6 & 100 \\ 1860-69 & - & 12 & 17 & 30 & 18 & 14 & 4 & 4 & 100 \\ 1870-79 & 1 & 11 & 19 & 25 & 20 & 13 & 5 & 5 & 100 \\ 1880-89 & - & 12 & 19 & 25 & 15 & 14 & 5 & 10 & 100 \\ 1890-99 & 1 & 11 & 22 & 20 & 13 & 15 & 6 & 13 & 100 \\ 1900-09 & 2 & 20 & 21 & 15 & 9 & 11 & 5 & 17 & 100\end{array}$

(b) Previously born child was stillborn or died before one year of age

$\begin{array}{rrrrrrrrrrr}1830-39 & 7 & 42 & 32 & 9 & 5 & 5 & - & - & 100 & (123) \\ 1840-49 & 8 & 36 & 21 & 12 & 8 & 8 & 4 & 3 & 100 & (132) \\ 1850-59 & 9 & 32 & 31 & 12 & 5 & 6 & 1 & 4 & 100 & (114) \\ 1860-69 & 8 & 44 & 25 & 9 & 5 & 3 & 2 & 4 & 100 & (149) \\ 1870-79 & 8 & 35 & 32 & 9 & 5 & 4 & 5 & 2 & 100 & (78) \\ 1880-89 & 6 & 34 & 17 & 13 & 4 & 2 & 11 & 13 & 100 & (47) \\ 1890-99 & - & 30 & 22 & 13 & 11 & 11 & 8 & 5 & 100 & (37) \\ 1900-09 & 13 & 40 & 27 & 7 & 7 & - & - & 7 & 101 & (15)\end{array}$

the changes of reproductive behavior associated with the beginning of the secular decline of marital fertility are the following. Predominantly natural fertility prevailed in the oldest four 10-year cohorts studied, i.e. the cohorts in which women were born in the years $1830-39,1840-49,1850-59$ and $1860-69$. Marital fertility of these cohorts was, however, at a modest level as birth intervals were prolonged by extended breast-feeding. The number of children in families was further restricted by high child mortality; a third of children did not survive into adulthood. The secular fertility decline began at the cohort $1870-79$ and this was also the first cohort whose fertility patterns showed signs of concious family limitation. Transformations of behavior related to fertility had already started, however, in the preceding two cohorts, in which infant and child mortality had started to decline and intervals between successive births to shorten. The behavioral change behind the shortening of birth intervals suggested by analysis of birth intervals was a change in breast-feeding habits.

The analyses of the reconstituted family histories do give direct information only about reproductive behavior and not about people's reproductive thinking and decisions. The results, however, suggest that a change in thinking about fertility was an essential component of the fertility transition. It was a unique change from natural fertility to family limitation which accompanied the secular fertility decline. No evidence was found to suggest that fertility would have been within the "calculus of concious choice» (Coale 1973, 3) before the onset of the fertility transition. Thus, it seems likely that the diffusion of the idea of family limitation was a central feature of the fertility transition. Other results from the analyses of the same data, some of which are reported elsewhere (Notkola 1989), also support this inference. For example, the fact that the decline of marital fertility started at the same time in different social groups is consistent with the view that the fertility transition was largely ideational change. In a culturally homogenous area, like Virolahti, the new mode of behavior spread quickly over the whole society apart from differences in the economic value of children in different social groups. Moreover, the fertility transition 
started in the research area earlier than in the country as a whole, and seemed not to be associated with any crucial economic changes. Instead, in social development the area was among the pioneers in the 19th century, for example communally based primary schools were founded comparatively early.

The sequence of the changes in child mortality, breast-feeding habits and fertility cannot be ignored in the discussion about the nature of fertility decline. One way to consider these changes is to look at them with regard to the availability and contents of publications on corresponding subjects. Finnish literature concerning child rearing became more widely available in the latter half of the nineteenth century (Lönnrot 1859, Backman 1864, Abelin 1875, Collan 1889 among others), whereas Finnish contraceptive and family planning literature was not published until the first decade of this century (see Nieminen 1951, 376-398). It is important also to note how advice given in child rearing literature changed from the middle of the nineteenth century to the beginning of this century. From the latter half of the nineteenth century women were advised to give up the habit of always feeding babies when they cried and, instead, to have a break lasting for two or three hours between successive suckling episodes. The age at which breast-feeding should be stopped was one year in the guides published in the nineteenth century, but it was decreased to eight or nine months at the beginning of this century. Following these instructions would shorten the period of lactational amenorrhoea, since it depends on the duration and intensity of breast-feeding. Although it is not clear how the advice given in the literature was received by the people, the results concerning birth intervals in this study suggest that in the last decades of the nineteenth century breast-feeding habits were changing towards the recommendations given in the child rearing literature. The onset of the decline of infant and child mortality may also be interpreted as a result of better child care practices adopted from the advice of experts. New practices of child care were followed by new reproductive behavior, family limitation, at the beginning of this century, i.e. at the same time as the propagation of the desirability of limiting fertility began. It seems most likely that the publication of family planning literature changed attitudes towards fertility and led people to ask the new question of »how many children should we have?» (cf. Woods 1987, 311).

In the case of Virolahti there is also another possible route through which the new ideas of family limitation may have reached the people, i.e. contacts with the people living in St. Petersburg and Estonia. Massive amounts of stone were transported from Virolahti for the building of St. Petersburg in the 19th and early 20th. Fishermen, on the other hand, used to sail to Estonia twice a year to exchange their autumn and spring catch for potatoes and grain. It seems possible that knowledge about family limitation - as well as perhaps about new contraceptive methods was got through these journeys, since the fertility transition started in these areas already in the last decades of the nineteenth century (Coale \& Watkins 1986, Map 2.1.).

\section{References}

Abelin, H. (1875). Lasten hoidosta ensimmäisina elinvuosina (Suomennos). (On child care during the first years of life. A translation). Helsinki.

Anderson, B.A. (1975). Male age and fertility results from Ireland prior to 1911. Population Index 41 (4): $561-567$

Backman, H. (1864). Tieteelliselle kannalle perustettu pienten lasten elanto ja hoito (Nutrition and care of small children grounded on scientific basis). Helsinki.

Billewicz, W.Z. (1979). The timing of post-partum menstruation and breast feeding: a simple formula. Journal of Biosocial Science 11 (2): 141-151. 
Bongaarts, J. (1982). The fertility-inhibiting effects of the intermediate fertility variables. Studies in Family Planning $13(6 / 7): 179-189$.

Coale, A.J. (1973). The demographic transition reconsidered: In: International Population Conference: Liège 1973, pp. 53-72. Liege: IUSSP.

Coale, A.J. and Treadway, R. (1986). A summary of the changing distribution of overall fertility, marital fertility and the proportion married in the provinces of Europe. In: The Decline of Fertility in Europe, edited by Ansley J. Coale and Susan Cotts Watkins, pp. 31-181. Princeton: Princeton University Press.

Coale, A.J. and Trussel, T.J. (1978). Technical note: finding the two parameters that specify a model schedule of marital fertility. Population Index 44 (2): 203-213.

Coale, A.J. and Watkins, Susan C. (eds.) (1986). The Decline of Fertility in Europe. Princeton: Princeton University Press.

Collan, J. (1889). Pienten lasten ruokkimisesta Pohjois-Karjalassa (On feeding small children in NorthCarelia). Suomen terveydenhoitolehti 5: 49-54.

Davis, K. and Blake, J. (1956). Social structure and fertility: an analytic framework. Economic Development and Cultural Change 4: $211-235$.

Gaunt, D. (1973). Family planning and the preindustrial society: some Swedish evidence. In: Aristorats, Farmers, Proletarians: Essays in Swedish Demographic History, edited by K. Ågren et al. Uppsala.

Henry, L. (1961). Some data on natural fertility. Eugenics Quarterly 8 (2): 81-91.

Howie, P.W. and McNeilly, A.S. (1982). Breast-feeding and postpartum ow lation. IPPF Medical Bulletin 16: $1-3$.

James, W.H. (1983). Decline in coital rates with spouses'age and duration of marriage. Journal of Biosocial Science 15 (1): 83-87.

Knodel, J. (1978a). European populations in the past: family level relations. In: The Effects of Infant and Child Mortality on Fertility, edited by S.H. Preston. New York.

Knodel, J. (1978b). Natural fertility in pre-industrial Germany. Population Studies 32 (3): 481-510.

Knodel, J. (1979). The influence of child mortality in a natural fertility setting: an analysis of German villages. In: Natural Fertility, edited by H. Leridon and J. Menken, pp. 273-284. Liege: IUSSP.

Konner, M. and Worthman, C. (1980). Nursing frequence, gonadal function, and birth spacing among !Kung hunter-gatherers. Science 207: 788-791.

Lindgren, Jarl (1980). Nuptiality and marital fertility during the first phase of industrialization in Finland. Yearbook of Population Research in Finland 18: 80-95.

Lithell, U.-B. (1981). Breast-feeding and reproduction. Studies in marital fertility and infant mortality in 19th century Finland and Sweden. Studia Historica Upsaliensia 120. Uppsala.

Lönnrot, E. (1859). Minkätähden kuolee niin paljo lapsia ensimmäisellä ikävuodellansa (Why so many infants die during their first year of life). Turku.

McCann, M.F. et al. (1984). Breast-feeding, fertility, and family planning. Population Reports, Ser. J. No. 24, 1981. Revised March 1984.

Nieminen, A. (1951). Taistelu sukupuolimoraalista : avioliitto- ja seksuaalikysymyksiä suomalaisen hengenelämän ja yhteiskunnan murroksessa sääty-yhteiskunnan ajoilta 1910-luvulle (Battle over sexual morals: problems of marriage and sex in Finland appr. from 1860 to 1920). Väestöpoliittisen tutkimuslaitoksen julkaisuja. Sarja A, nro 6. Helsinki: WSOY and Väestöpoliittinen tutkimuslaitos. Doctoral Thesis.

Notkola, I.-L. (1989). Luonnollisesta hedelmällisyydestä lapsirajoitukseen: mikrodemografinen tutkimus hedelmällisyyden transitiosta (From natural fertility to family limitation: a family reconstitution study of fertility transition in Finland) Suomen Väestötieteen Yhdistyksen julkaisuja N:o 12. Helsinki: Suomen Väestötieteen Yhdistys. Doctoral thesis.

Raussi, E. (1966). Virolahden kansanelämää 1840-luvulla (On life of ordinary people in Virolahti in the 1840s). Suomalaisen kirjallisuuden seuran toimituksia 280. Helsinki: Suomalaisen Kirjallisuuden Seura.

Van de Walle, E. and Knodel, J. (1980). Europe's fertility transition: new evidence and lessons for today's developing world. Population Bulletin 34 (6).

Wilson, C. (1984). Natural fertility in pre-industrial England, 1600-1799. Population Studies 38 (2): $225-240$.

Winberg, C. (1975). Folkökning och proletarisering. Meddelanden från historiska institutionen i Göteborg, Nr. 10. Göteborg.

Woods, R.I. (1987). Approaches to the fertility transition in Victorian England. Population Studies 41 (2): $283-311$.

Wrigley, E.A. (1966). Family limitation in pre-industrial England. The Economic History Review (2nd series) No. 19, pp. 82-109. 